
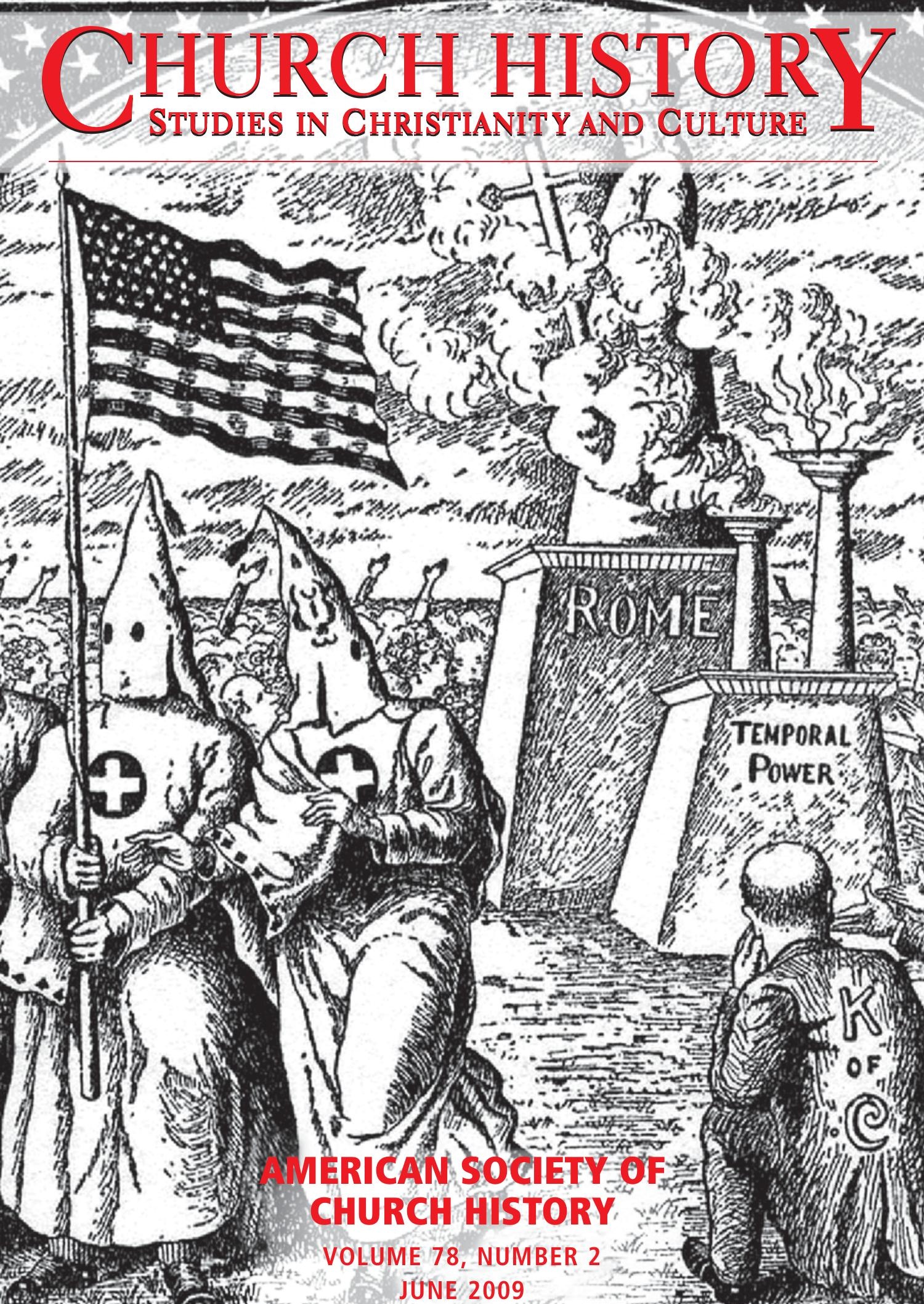


\title{
THE AMERICAN SOCIETY OF CHURCH HISTORY
}

\author{
PRESIDENT \\ CHARLES H. LIPPY, University of Tennessee at Chattanooga \\ PRESIDENT-ELECT \\ RICHARD P. HEITZENRATER, Duke University \\ EXECUTIVE SECRETARY \\ KEITH A. FRANCIS, Baylor University \\ EDITORS \\ JOHN CORRIGAN \\ AMANDA PORTERFIELD \\ Florida State University \\ MEMBERS OF THE COUNCIL
}

Class of 2009

JOHN M. GIGGIE

PATRICIA Z. BECKMAN

TIMOTHY TSENG

J. PATOUT BURNS

CANDY GUNTHER BROWN

Class of 2010

CHRISTOPHER BEELEY

KATHLEEN SPROWS CUMMINGS

STEVEN L. OLSEN

QUINCY D. NEWELL

Class of 2011

MARGARET BENDER

SUSAN E. SCHREINER

SCOTT W. SUNQUIST

FR. AUGUSTINE THOMPSON, O.P.

Council Student Representative 2009-2010

BRANDON BAYNE

The Society was founded in 1888 by Philip Schaff, was reorganized in 1906, and was incorporated by act of the Legislature of the State of New York in 1916. 


\title{
$\begin{array}{lll}\text { Vol. } 78 \quad \text { June } 2009 & \text { No. } 2\end{array}$
}
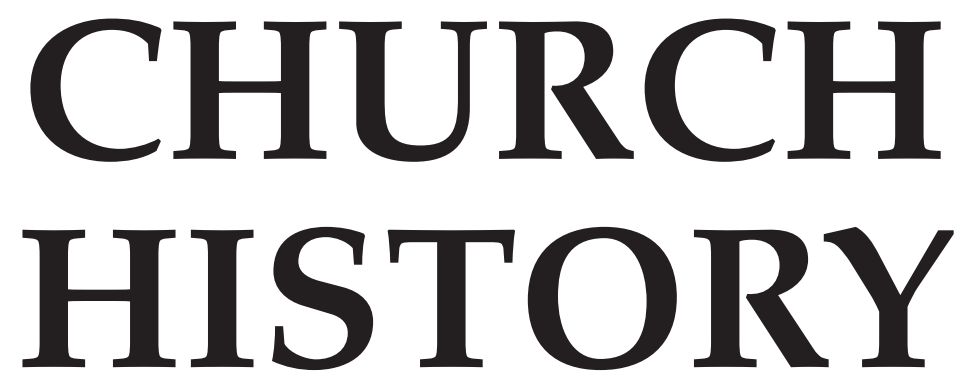

\section{Studies in \\ Christianity $\mathcal{E}$ Culture}

\author{
Published quarterly by \\ THE AMERICAN SOCIETY OF CHURCH HISTORY
}

(C) 2009, The American Society of Church History 


\title{
CHURCH HISTORY \\ Studies in Christianity and Culture
}

\author{
Editors \\ John Corrigan \\ Amanda Porterfield \\ Senior Assistant to the Editors \\ Monica Reed \\ Assistants to the Editors \\ Brooke Sherrard \\ Shaun Horton \\ Tammy Heise
}

\section{FLORIDA STATE UNIVERSITY}

Associate Editors

Elizabeth A. Clark

Thomas Noble

Carlos Eire

Hugh McLeod

Dana Robert

Myung Soo Park

Enrique Dussel

Church History (ISSN 0009-6407) 


\section{ARTICLES}

261 Preacher Politics and People Power: Congregational Conflicts in New York City, 1810-1830 Kyle T. Bulthuis

283 "Unashamed of the Gospel": Johann Hinrich Wichern and the Battle for the Soul of Prussian Prisons Albert Wu

309 An Egyptian in China: Ahmed Fahmy and the Making of "World Christianities" HEATHER J. SHARKEY

327 Caring Beyond National Borders: The YMCA and Chinese Laborers in World War I Europe Peter Chen-main Wang

350 Christianizing the Klan: Alma White, Branford Clarke, and the Art of Religious Intolerance LYNN S. NEAL

\section{BOOK REVIEWS AND NOTES}

379 Conway, Colleen M., Behold the Man: Jesus and Greco-Roman Masculinity L. Stephanie Cobb

Martin, Dale B., Inventing Superstition from the Hippocratics to the Christians Svetla Slaveva-Griffin

384 Kahlos, Maijastina, Debate and Dialogue: Christian and Pagan Cultures, c. $360-430$ Jeremy Schott

Gwynn, David M., The Eusebians: The Polemic of Athanasius of Alexandria and the Construction of the "Arian Controversy". Rebecca Lyman

387 Wormald, Patrick, and Janet L. Nelson, eds., Lay Intellectuals in the Carolingian World Geoffrey Koziol

390 Loud, G. A., The Latin Church in Norman Italy Neslihan Senocak

Purkis, William J., Crusading Spirituality in the Holy Land and Iberia, c. $1095-$ c. 1187 Christopher Tyerman

394 Watkins, Carl S., History and the Supernatural in Medieval England Jeffrey Burton Russell

396 Clark, James G., The Culture of Medieval English Monasticism. 
401 Bourdua, Louise, and Anne Dunlop, eds., Art and the Augustinian Order in Early Renaissance Italy Joseph P. Byrne

403 Evangelisti, Silvia, Nuns: A History of Convent Life, 1450-1700.

Sherri Franks Johnson

406 Giffords, Gloria Fraser, Sanctuaries of Earth, Stone, and Light: The Churches of Northern New Spain, 1530-1821 Peter W. Williams

406 Durston, Alan, Pastoral Quechua: The History of Christian Translation in Colonial Peru, 1550-1650 Michael A. Uzendoski

409 Jackson, Nicholas D., Hobbes, Bramhall and the Politics of Liberty and Necessity: A Quarrel of the Civil Wars and Interregnum.

William M. Abbott

Roeber, A. G., Ethnographies and Exchanges: Native Americans, Moravians, and Catholics in Early North America ................... Katherine Carté Engel

413 Fea, John, The Way of Improvement Leads Home: Philip Vickers Fithian and the Rural Enlightenment in Early America Kerry Walters

415 Ruffin, J. Rixey, A Paradise of Reason: William Bentley and Enlightenment Christianity in the Early Republic..... Kirsten Fischer

Irons, Charles F., The Origins of Proslavery Christianity: White and Black Evangelicals in Colonial and Antebellum Virginia. John B. Boles

Byrnes, Joseph F., Catholic and French Forever: Religious and National Identity in Modern France. Edward J. Woell

Callahan, Richard J., Jr., New Territories, New Perspectives: The Religious Impact of the Louisiana Purchase.... Michael Pasquier

Ramsay, Jacob, Mandarins and Martyrs: The Church and the Nguyen Dynasty in Early Nineteenth-Century Vietnam..... Jean Michaud

Monroe, John Warne, Laboratories of Faith: Mesmerism, Spiritism, and Occultism in Modern France. Bret E. Carroll

Farmer, Jared, On Zion's Mount: Mormons, Indians, and the American Landscape. Quincy D. Newell

Maffly-Kipp, Laurie F., and Reid L. Neilson, eds., Proclamation to the People: Nineteenth-Century Mormonism and the Pacific Basin Frontier.

Randi Jones Walker

Davis, Morris L., The Methodist Unification: Christianity and the Politics of Race in the Jim Crow Era. Richard J. Callahan, Jr.

Hall, Amy Laura, Conceiving Parenthood: American Protestantism and the Spirit of Reproduction.... Margaret Bendroth

Bergunder, Michael, The South Indian Pentecostal Movement in the Twentieth Century.....

Dale T. Irvin

440 Chandler, Andrew, The Church of England in the Twentieth Century: The Church Commissioners and the Politics of Reform, $1948-1998$. William H. Petersen

Lamb, Matthew L., and Matthew Levering, eds., Vatican II: Renewal Within Tradition. Maura Jane Farrelly

444 Garrard, John, and Carol Garrard, eds., Russian Orthodoxy Resurgent: Faith and Power in the New Russia. John D. Basil

Umble, Diane Zimmerman, and David L. Weaver-Zercher, eds., The Amish and the Media ..... Kristy Nabhan-Warren

449 Kriebel, David W., Powwowing among the Pennsylvania Dutch: A Traditional Medical Practice in the Modern World. Gary L. Ebersole 
451 Rommen, Timothy, "Mek Some Noise": Gospel Music and the Ethics of Style in Trinidad. Ennis B. Edmonds

454 McGuckin, John Anthony, The Orthodox Church: An Introduction to its History, Doctrine, and Spiritual Culture. Robert R. Phenix, Jr.

457 González, Ondina E., and Justo L. González, eds., Christianity in Latin America: A History.... Iain S. Maclean

458 Worcester, Thomas, The Cambridge Companion to the Jesuits

Hilmar M. Pabel

461 Fitzgerald, Timothy, Discourse on Civility and Barbarity: A Critical History of Religion and Related Categories Kathryn Lofton

463 Conser, William H., Jr., and Rodger M. Payne, eds., Southern Crossroads: Perspectives on Religion and Culture. Charles F. Irons

466 Robert, Dana L., Converting Colonialism: Visions and Realities in Mission History, 1706-1914 Emma Wild-Wood

O'Toole, James M., The Faithful: A History of Catholics in America

Sharon M. Leon

470 Cohen, Charles L., and Paul S. Boyer, eds., Religion and the Culture of Print in Modern America Peter J. Wosh

Hankins, Barry, American Evangelicals: A Contemporary History of a Mainstream Religious Movement. Lewis V. Baldwin

\section{Books ReCEIVED}

\section{Society Notices}

